D. Ptaschenko, Cand. Sc. (Law), Assist.

Taras Shevchenko National University of Kyiv, Kyiv, Ukraine

\title{
FORMATION OF THE UKRAINIAN LEGAL DOCTRINE CONCERNING QUALIFICATION OF THE CRIMINAL OFFENSES COMMITTED BY THE ORGANIZED CRIMINAL GROUPS IN CONTEXT OF AMENDING CHANGES TO LEGISLATION ON CRIMINAL LAW
}

The Article 1 of the Constitution of Ukraine regulates: Ukraine is a sovereign and independent, democratic, social, legal state. One of the destabilizing factors in building the rule of law is the commission of criminal offenses by organized criminal groups. Due to the changes in the criminal legislation during the last two years, the criminal law norms have undergone significant changes, which directly or indirectly affect the qualification of criminal offenses committed by organized criminal groups.

Given the changes in criminal law, the qualification of criminal offenses committed by organized criminal groups requires uniform systemic approaches, primarily at the level of judicial law enforcement practice. The formation of the Ukrainian legal doctrine on the qualification of criminal offenses committed by organized criminal groups is one of the significant auxiliary guidelines in the formation of such law enforcement practice.

To achieve this goal and the defined objectives, the following methods were applied in the study: logical and normative - for the analysis of criminal law on the qualification of criminal offenses committed by organized criminal groups; system analysis - when considering judicial law enforcement practice (first of all, the Supreme Court and the Supreme Court of Ukraine) of the qualification of criminal offenses committed by organized criminal groups.

The legislation strengthens criminal liability for criminal offenses by organized criminal groups, in particular, as evidenced by the amendments to the Criminal Code under the Law of Ukraine "On Amendments to Certain Legislative Acts of Ukraine on Liability for Crimes Committed by the Criminal Community" dated by the $4^{\text {th }}$ of June 2020.

Before the formation of new approaches to the doctrine of criminal law and law enforcement judicial practice on the qualification of criminal offenses (crimes), a specific part of which is provided by h.ch. 1-5 art. 255 of the Criminal Code, the indirect reference is the provision of the resolution of the Plenum of the Supreme Court of Ukraine of December 23, 2005 №12 "On the practice of consideration by courts of criminal cases on crimes committed by stable criminal groups."

Keywords: criminal offenses, criminal community, criminal organization, organized group, creation of a criminal community, leadership of a criminal community, organized criminal groups.

Bulletin of Taras Shevchenko National University of Kyiv. Legal Studies, 2021; 4 (118): 116-122

УДК 347.611

DOI: https:doi.org/10.17721/1728-2195/2021/3.118-21
ISSN 1728-2195

(C) Taras Shevchenko National University of Kyiv, Publishing center "Kyiv University", 2021

Л. І. Радченко, канд. юрид. наук, доц. Київський національний університет імені Тараса Шевченка, Київ, Україна ORCID ID: 0000-0002-3783-9489

\section{ПРАВОВЕ РЕГУЛЮВАННЯ РОЗІРВАННЯ ШЛЮБУ: ІСТОРИЧНИЙ РОЗВИТОК І СУЧАСНІ ЗАСАДИ}

Досліджено генезис правового регулювання порядку, умов і наслідків розірвання шлюбу в його історичному аспекmi, а також з огляду на сучасні засади регламентації сімейних відносин у праві ЄС та у законодавстві окремих іноземних держав, висвітлено новітні тендениії розвитку відносин у сфері розлучень й окреслено закономірності їхнього подальшого нормативного закріплення у сімейному праві України, сформульовано висновки і пропозиції, спрямовані на гармонізацію національного законодавства з правом ЄС.

Наголошено, що процедура розлучення, їі умови та правові наслідки регулюються законодавством різних держав по-різному. На зазначені відносини також суттєво впливають національні особливості, традиції, релізія та культура. Поширення сімейних правовідносин за межі однієї держави викликає необхідність застосування для регулювання таких відносин іноземного законодавства. Наслідком застосування права різних держав щодо підстав розлучення, процедури розірвання шлюбу, а також неоднакового визначення моменту його припинення, може стати виникнення відповідних колізій. Зазначене зумовлює практичне значення визнання наслідків розлучення, здійсненого за правом однієї держави в іноземних правопорядках.

Одним з основних принципів римського приватного права було дотримання принципу абсолютної свободи розлучення. Проте в імператорський період, та особливо з утвердженням християнства, були встановлені обмеження для розлучення. Підхід щодо суттєвого обмеження, та навіть заборони розлучення, упродовж тривалого часу спостерігався у праві європейських держав. Під впливом католицької церкви та християнської моралі рецепійоване римське право взагалі не допускало розлучення чи встановлювало обмеження та вагомі підстави для розлучення. Починаючи з другої половини XX cm., у багатьох країнах проведено реформи законодавства про розлучення, унаслідок яких розлучення стали більш лібералізованими.

Загальним колізійним принципом розірвання шлюбу визнається закон громадянства подружжя (більшість країн континентальної Європи) або закон місця проживання подружжя (Англія та ін.). Однак, Регламент ЄС $1259 / 2010$ передбачає інноваційні положення щодо обрання компетентного правопорядку у разі розлучення, закріплюючи можливість самостійного обрання подружжям застосовного права.

Ключові слова: шлюб, шлюбні відносини, розірвання шлюбу, розлучення, припинення шлюбу, право ЄС, сімейне право.

\section{ВСТУП}

Інститут шлюбу, так само як інститут сім'ї, $є$ базовою, основоположною сферою правової регламентації сімейного права будь-якої держави. Аналізу його правової природи, особливостей укладання і розірвання та зумовлених цими фактами правових наслідків завжди приділялась достатньо велика увага з боку юридичної науки. Поряд із цим, у сучасних умовах розвитку суспільства, зростання рівня міграції населення, посилення міжнародного культурного обміну та співробітництва спостерігається поступове переоцінювання, зміна основних засад регламентації цього традиційного правового інституту.
На регулювання відносин із розірвання шлюбу суттєво впливають національні особливості, традиції, релігія та культура. Поширення сімейних правовідносин за межі однієї держави пояснюється наявністю в цих відносинах правової категорії "іноземний елемент", що викликає необхідність застосування до таких відносин іноземного законодавства. Наслідком застосування законодавства різних держав може стати виникнення відповідних колізій.

Зазначене зумовлює актуальність розгляду проблематики розвитку правового регулювання умов, порядку та наслідків розірвання шлюбу як у його історичному контексті, так і з огляду на сучасні тенденції регламен- 
тації сімейних відносин за законодавством ЄС, у праві України й окремих іноземних держав.

Проблематика сімейних відносин через призму міжнародного приватного права була предметом наукового дослідження українських науковців, зокрема, Т. В. Боднар, А. С. Довгерта, О.В. Дзери, В. І. Кисіля, В. І. Труби та інших учених, а також представників правової доктрини іноземних держав.

Методологія дослідження. У процесі написання статті використано загальнонаукові і спеціальноюридичні методи дослідження правових явищ і юридичних категорій, зокрема, порівняльно-правовий, історичний, формально-логічний та інші методи.

Метою цієї публікації $є$ дослідження генезису правового регулювання порядку, умов і наслідків розірвання шлюбу в його історичному аспекті, а також сучасних засад регламентації сімейних відносин у праві $€ С$ та за законодавством іноземних держав, висвітлення новітніх тенденцій регулювання відносин із розлучення та окреслення закономірностей їхнього подальшого нормативного закріплення у сімейному праві України.

\section{ОСНОВНІ РЕЗУЛЬТАТИ}

Розірвання шлюбу у міжнародному сімейному праві породжує численні колізії. На такі зіткнення правових систем неодноразово звертали увагу провідні українські вчені, серед яких слід назвати А. С. Довгерта, В. І. Кисіля [1; 2]. Адже розлучення, зокрема його процедура, регулюються законодавством різних держав по-різному. Крім того, є держави, в яких інститут розлучення взагалі відсутній або допускається у дуже вузьких межах.

Рішення про розірвання шлюбу за участю іноземців, як правило, підлягає визнанню у тих державах, де розлучене подружжя може мати певні інтереси, що свідчить про небажаність так званих "шкутильгаючих розлучень", тобто коли подружжю в одній країні дозволили розлучення, проте на батьківщині одного з них, або їх обох, такий дозвіл не визнається і вони продовжують юридично залишатися чоловіком і дружиною. Певної гостроти набуває колізія зіткнення матеріального права різних країн щодо підстав розлучення, процедури розірвання шлюбу через реєстраційні органи та суди, а також неоднакового визначення моменту припинення шлюбу. Зазначене зумовлює практичне значення визнання наслідків розлучення, здійсненого за правом однієї держави в іноземних правопорядках.

У зв'язку з наведеним, окреслимо основні історичні засади розвитку правового регулювання порядку, умов і наслідків розірвання шлюбу у праві європейський держав.

У римському приватному праві протягом тривалого часу існування Римської держави діяв принцип свободи розлучення. Відомі різні підстави та порядок розлучення в шлюбі cum manu i sine manu. У шлюбі cum manu, де юридична особистість дружини поглиналася особистістю чоловіка, розлучення здійснювалося тільки за волею чоловіка або його pater familias. Шлюб sine manu розривався не тільки за бажанням подружжя (divortium), але і в односторонньому порядку за волевиявленням як чоловіка, так і дружини (repudium). Незважаючи на велику кількість розлучень, укладення другого шлюбу після припинення попереднього не мало до певного часу жодних обмежень [3, с. 149].

Можливість неформального розлучення за першим бажанням будь-кого 3 подружжя зумовило виникнення питання про інтерпретацію волі у разі сімейних спорів або тривалої розлуки. У такому випадку швидке повернення в сім'ю дозволяло вважати, що сварка не була розлученням, навіть якщо в запалі гніву була висловлена заява про припинення шлюбу [4, с. 322]. Навіть тривала розлука сама по собі не вважалася розлученням, якщо намір розірвати шлюб не був вираженим, хоча б на рівні поведінки одного з подружжя. Але така свобода, у свою чергу, породжувала певні негативні наслідки в суспільстві. В імператорський період встановлюються суттєві обмеження для розлучення.

Свобода укладення та розірвання шлюбу зазнала суттєвих непрямих обмежень при Августі, коли були прийняті два закони про порядок укладання шлюбу: lex lulia de maritandis ordinibus 18 р. до н. е. i lex Papia Рорраеа 9 р. н. е., які науковці часто трактують як один нормативний акт: lex lulia et Papia [4, с. 323]. Закон забороняв вільнонародженим громадянам вступати в шлюб із вольновідпущеницями, з жінками, викритими в перелюбстві, а також з актрисами та із засудженими жінками. Прагнучи стимулювати укладання законних римських шлюбів і створення потомства, закони обмежували заповідальну правоздатність, невід'ємне право римського громадянина, вводячи нову категорію incapacitas. Закони забороняли отримувати спадщину (за заповітом або за законом) холостякам і вдівцям шлюбного віку (25-60 років) або вдовам (20-50 років), які не уклали новий шлюб. Одруженим, але бездітним дозволялось отримувати лише половину спадщини. Інший закон Августа 18 р. до н. e. - lex lulia de adulteriis coercendis (про приборкання перелюбств) - установлював покарання у вигляді вислання на острови (relegatio in insulam) у разі зради дружини, роблячи виняток лише для актрис, вольновідпущениць та інших жінок низької моралі. Такий наслідок стосувався лише жінок. Чоловіки переслідувалися за розпусту (stuprum), якою вважався будь-який неправильний шлюб.

Законодавство Августа було націлене на природне зростання кількості римських громадян: звідси заходи зі зміцнення сім'ї, заохочення правильних (законних) шлюбів і обмеження позашлюбних зв'язків, від яких не могли народитися римські громадяни.

У посткласичний період під впливом християнства безшлюбність стали розглядати як нормальне явище. Закони Августа поступово виходять з ужитку. Імператор Костянтин скасовує accusatio publica iure extranea (публічне звинувачення, доступне будь-якій сторонній особі) і встановлює, що тільки близькі родичі і чоловік можуть звинуватити жінку в подружній зраді. При Юстиніані встановлюється правило, за яким дружина, викрита у перелюбстві, довічно направляється в монастир, але чоловік протягом двох років може повернути її до себе [4, с. 324].

Таким чином, одним з основних принципів римського приватного права було дотримання абсолютної свободи розлучень. Проте з утвердженням християнської релігії були встановлені дуже істотні обмеження. За взаємною згодою розлучення було заборонено. Поступово, вироблялися вагомі підстави до розлучення: порушення подружньої вірності, посягання на життя одного з подружжя, нездатність до дітонародження, до шлюбного життя, вступ до монастиря одного з подружжя тощо.

Підхід щодо суттєвого обмеження, та навіть заборони розлучення, упродовж тривалого часу спостерігався також у праві європейських держав. Рецепійоване римське право під впливом християнської моралі взагалі не допускало розлучення чи встановлювало сурові обмеження та вагомі підстави для розлучення.

В одній із перших цивільних кодифікацій в Європі Цивільному кодексі для Східної Галичини 1797 р. (лат. Codex civilis pro Galicia Orientali) [5] - можливість розлучення була суттєво обмежена. Саме Цивільний кодекс для Східної Галичини від 1797 р. покладено в основу Цивільного кодексу Австрії 1811 р. та базовано на рецепції римського права. Він був побудований за інституційною системою, написаний латинською мовою та містив багато запозичень із римського права.

Згідно з п. 102 Цивільного кодексу для Східної Галичини було закріплене загальне правило про розірвання шлюбу лише смертю одного з подружжя: "шлюбний зв'язок, який $€$ наявним між католиками з дотриманням ритуа- 
лу, може бути розірвано лише смертю одного з подружжя. Те саме право нехай буде щодо мішаних шлюбів католиків з некатоликами, укладених на законних підставах" [5]. Положення п. 93 також закріплювало правило про заборону розлучень - "немає жодного інтересу ані для суспільства, ані для дітей, які народжені у шлюбі, у тому, щоб відбувалися розлучення та руйнувалися шлюби. Подружжю не дозволено та нехай у них не буде такого права розлучатися на власний розсуд, крім як за умови, що вони розлучаються дружелюбно та за взаємною згодою, а також у випадку нікчемності укладеного шлюбу, або повного скасування законного шлюбу за їхнім бажанням, або, нарешті встановленого відлучення "від стола та ложа".

"Відлучення від стола та ложа" за проханням однієї сторони за наявності заперечень другої допускалося; по-перше, якщо один із подружжя скоїть зраду; подруге, якщо один із подружжя залишить другого і не з'явиться упродовж року, після того як рішенням судді або державним указом буде встановлено, що його місцезнаходження невідомо; по-третє, якщо один із подружжя погано та нелюдяно поводився з другим та його життя, здоров'я, більша частина майна та його добре ім'я внаслідок поганого поводження (другого з подружжя) були поставлені у скрутне становище (п. 108) [5].

Процедура розлучення за взаємною згодою також була дуже складною, при цьому основну роль у ній відігравав священнослужитель. Подружжя, яке прийняло за взаємною згодою рішення розлучитись або перебувати у стані "відлучення від стола та ложа", повинно сповістити про своє рішення та про його підстави своєму священнослужителю. Священик має нагадати подружжю про взаємні обіцянки у вірності, які були надані під час здійснення священного обряду укладення шлюбу, про шлюбний зв'язок, а також дуже серйозно та неодноразово говорити про згубні наслідки можливого розлучення. Після трикратного марно здійсненого нагадування нехай буде зроблено письмове засвідчення про наполегливе рішення подружжя, яке не переконали жодні доводи про розлучення. Після отримання цього свідоцтва, подружжя постає перед суддею в суді та в письмовому вигляді подає прохання про розлучення. Суддя без розгляду обставин розлучення нехай надасть їм рішення про розірвання шлюбу та відобразить його у судових документах (п. 103-106) [5].

Таким чином, право європейських держав під впливом католицької церкви та християнської моралі встановлювало заборону розлучення та лише як виняток, за наявності істотних обставин і бажання подружжя, 3 додержанням ускладнених процедур передбачало можливість розірвання шлюбу.

Проблема розлучення була та до останнього часу $є$ однією з найскладніших у країнах з християнською традицією, у силу якої шлюб є священним, довічним союзом, що не може бути розірваний. Хоча ця жорстка норма постійно вступала у конфлікт з реаліями життя, проте розлучення впродовж тривалого часу не допускалося в Італії, Іспанії та деяких країнах Латинської Америки. Водночас, у правових системах, де загалом розлучення було можливим, отримати розлучення досить складно, оскільки, з одного боку, сама процедура розлучення була вартісною, а з іншого - розлучення допускалось законом тільки в обмежених випадках і за визначених підстав. Причому розлучення розглядалось у межах майже всіх правових систем як санкція за винну поведінку подружжя, за порушення договору у вигляді його припинення, зі стягненням збитків і в деяких випадках - з відшкодуванням моральної шкоди.

Починаючи з другої половини $60-x$ років XX століття у багатьох країнах були проведені реформи законодавства про розлучення, тенденцією яких стала відмова від ідеї, що розлучення - це санкція за винну поведінку подружжя, та перехід до концепції, що розлучення - це констатація невдалого шлюбу. Унаслідок реформ розлучення стали більш лібералізованими.

На підставі реформ у сфері розлучень суттєво змінилося законодавство багатьох держав. Так, у Франції внаслідок проведеної реформи у сфері розлучення прийнято Закон про розлучення від 26 травня 2004 року. Відповідно до цього Закону були внесені зміни у ст. 229 ЦК Франції, яка регулює питання про розлучення таким чином: рішення про розлучення може бути винесено у разі: або взаємної згоди; або за згодою із принципом розірвання шлюбу; або у зв'язку з остаточною зміною подружніх відносин; або з вини одного з подружжя.

Загалом у законодавстві Франції існує три можливі моделі організації спільного життя: шлюб ("marriage"); цивільний пакт солідарності ("pacte civil de solidarité"); режим спільного проживання ("concubinage"). Питанню шлюбу присвячений титул V "Про шлюб" Книги I "Про осіб" (ст. 143-227) Цивільного кодексу Франції [6]. Визначення поняття "шлюб" у законодавстві Франції відсутнє, але з урахуванням змісту ст. 143 ЦК Франції: "Шлюб укладається між двома особами різної або однієї статі", ми можемо зробити висновок, що фрранцузький законодавець розуміє під шлюбом союз між двома особами різної або однієї статі. Поправка щодо можливості укладення шлюбу між особами однієї статі була внесена до ЦК Франції Законом № 2013-404 від 17 травня 2013 р. [7].

У законодавстві Франції передбачено дві підстави розірвання шлюбу: смерть одного з подружжя та розлучення, проголошене в законному порядку (ст. 227 ЦК Франції) [6].

Розлучення може бути проголошене з таких підстав: за взаємною згодою сторін, на підставі "прийняття принципу розпаду шлюбу"; у зв'язку з остаточним зникненням сімейного зв'язку; через вчинення одним із подружжя одного або повторюваного серйозного порушення прав і обов'язків у шлюбі, що робить неможливим подальше сімейне життя (підстави, перераховані в ст. 229 ЦК). Розлучення за взаємною згодою може відбутися як у судовому, так і в позасудовому порядку, шляхом підписання подружжям угоди про розірвання шлюбу, яка посвідчується нотаріально в присутності адвокатів обох сторін (ст. 229-232 ЦК Франції).

Підстава "прийняття принципу розпаду шлюбу" застосовується, якщо обоє з подружжя бажають розлучитися, але не досягли згоди щодо наслідків розлучення (здійснення батьківської влади над дітьми, визначення місця проживання дитини, майнові питання), відбувається в судовому порядку (ст. 232-234 ЦК Франції). Розлучення через зникнення подружнього зв'язку може бути проголошене за заявою одного з подружжя, якщо подружжя не проживає спільно принаймні впродовж року до дати подачі такої заяви (ст. 237-238 ЦК Франції).

Також доволі поширеною підставою розлучення у Франції є вчинення одним із подружжя одного або повторюваного серйозного порушення прав і обов'язків у шлюбі, що робить неможливим подальше сімейне життя. До таких порушень належить насильство щодо дітей або іншого з подружжя, подружня зрада, відмова робити внесок до бюджету сім'ї (ст. 242-246 ЦК Франції).

У Німеччині реформа законодавства про розлучення була проведена у 1976-1977 pp. і завершилась прийняттям нового Закону. Зокрема, німецький законодавець відмовився від концепції винної поведінки подружжя і встановив основоположний принцип для вирішення питання про розірвання шлюбу - принцип остаточного й непоправного розладу сімейного життя, доказом якого може служити повна відсутність спільного проживання подружжя без надії на його відновлення. Проте у розлученні може бути відказано, якщо того вимагатимуть інтереси неповнолітніх дітей.

Німецький шлях розірвання шлюбу $є$ досить тривалим навіть за наявності згоди з боку подружжя на розлу- 
чення. До початку процедури розлучення подружжя повинно прожити окремо не менше одного року, а термін розгляду справи в суді може затягнутися до трьох років.

Наразі процедура розірвання шлюбу регламентована розд. 7 четвертої книги Німецького цивільного уложення та передбачає такі підстави для розірвання шлюбу [8]: шлюб розривається у судовому порядку за заявою одного або обох із подружжя за наявності таких умов: непоправний фактичний розпад шлюбу, одним із доказів якого $€$ роздільне проживання подружжя не менше одного року, якщо продовження шлюбу було б для заявника нестерпно жорстоким із причин, що пов'язані з особою іншого з подружжя. Презюмується, що шлюб непоправно розпався, якщо обидва з подружжя проживають окремо протягом трьох років, і шлюб розривається незалежно від згоди одного 3 подружжя. Шлюб також вважається таким, що непоправно розпався, якщо подружжя живе окремо не менше року і обидва 3 подружжя подають заяву про розірвання шлюбу або один із подружжя погоджується із заявою про розлучення, яку подано іншим із подружжя.

Законодавство Швейцарії містить такі підстави для розлучення: а) подружня зрада; б) замах на життя, побої чи тяжкі образи; в) учинення ганебного для іншого з подружжя правопорушення або ведення недостойного образу життя; г) залишення сім'ї щонайменше на два роки; д) душевна хвороба одного з подружжя протягом трьох років за наявності експертного висновку про невиліковність хвороби; є) неможливість спільного проживання. Причому невинний у розлученні один із подружжя, чиї майнові інтереси порушені, управі отримати справедливе відшкодування від винної сторони - іншого з подружжя.

У Нідерландах розлучення за взаємною згодою було визнано Верховним судом. Так, відповідно до Цивільного кодексу та Закону про розлучення від 1 січня 1993 року [9] у разі розлучень принцип вини втратив значення; дозволені розлучення з обопільної згоди подружжя і на єдиній підставі - незворотний розпад шлюбу. Відповідно до законодавства Нідерландів розлучення здійснюється судом із певними правовими наслідками для обох із подружжя. Так, після розлучення той із подружжя, який є більш забезпеченим фрінансово, зобов'язаний підтримувати іншого з подружжя - непрацездатну особу. Крім того, вони продовжують відповідати за утримання дітей.

Законодавство Італії кваліфікує розлучення як остаточне припинення статусу, що був створений шлюбом. Відтак, особи, що раніше перебували у шлюбі, можуть укласти новий шлюб, і у цьому випадку припиняється спільність майна. Відповідно до ст. 149 Цивільного кодексу Італійської Республіки, "підставами розірвання/припинення шлюбу є смерть одного з подружжя або інші підстави, передбачені законом" [10]. Підстави розлучення в Італії встановлено у ст. 3 Закону від 1 грудня 1979 року № 898 "Регулювання випадків розірвання шлюбу" [11], якою встановлено такі обставини, на підставі яких один з подружжя може просити про розірвання та скасування юридичних наслідків шлюбу: якщо після укладення шлюбу другий з подружжя був засуджений за злочин, навіть учинений раніше, який передбачає встановлення найвищої міри покарання або засудження до 15 років позбавлення волі, якщо другий із подружжя засуджений за певні види злочинів, якщо другий із подружжя засуджений за вбивство або замах на вбивство дитини або другого з подружжя, якщо другий із подружжя (громадянин іншої держави) отримав за кордоном скасування та припинення шлюбу й уклав в іншій країні інший шлюб, якщо шлюб не набув чинності з причини відсутності шлюбного зв'язку і було отримане судове рішення щодо зміни статі другим із подружжя.

Обов'язковою умовою розлучення $€$ встановлення режиму сепарації. Якщо розлучення відбувається за згодою сторін, то йому має передувати окреме проживання тривалістю 6 місяців, а якщо за бажанням одного з подружжя - подружжя повинно проживати окремо впродовж року до дати подачі заяви про розлучення. Розлучення може бути проголошене без установлення режиму сепарації, якщо один із подружжя вчинив тяжкий злочин, є іноземцем і розірвав шлюб за кордоном або в законному порядку змінив стать.

Найліберальнішим європейським законодавством у сфрері розлучень можна назвати законодавство Швеції. Так, відповідно до Закону 1974 р. шлюб може бути розірвано за заявою однієї зі сторін; при цьому позивач не зобов'язаний пояснювати суду причини розлучення, а суд - перевіряти, чи дійсно відбувся розпад шлюбу. Якщо інше подружжя не заперечує проти розлучення, то шлюб розривається без призначення будь-яких строків. Якщо у подружжя $€$ неповнолітні діти, то суд призначає шестимісячний термін для обмірковування, після закінчення якого у випадку повторного прохання позивача суд зобов'язаний розірвати шлюб без дослідження причин розлучення. Такий підхід пояснюється концепцією невтручання держави в особисте життя своїх громадян.

В Англії нині розлучення може бути отримано тільки за однієї підстави - непоправний розпад шлюбу, на підтвердження чого позивач повинен довести наявність однієї 3 таких п'яти причин: а) подружня зрада відповідача і неможливість унаслідок цього для позивача подальшого проживання з відповідачем; б) інша поведінка відповідача, яка виключає можливість продовження спільного життя; в) залишення відповідачем сім'ї на строк не менше трьох років, які безпосередньо передують подачі заяви, за умови згоди відповідача на розлучення; г) роздільне проживання подружжя протягом не менше двох років, які безпосередньо передують поданню заяви; д) жорстоке поводження; е) невиліковна душевна хвороба одного з подружжя за умови перебування на лікуванні не менше п'яти років до звернення подружжя-позивача до суду.

Колізійні норми щодо врегулювання розірвання шлюбу містяться як у нормах внутрішнього законодавства держав, так і в міжнародних угодах, зокрема, договорах про правову допомогу, консульських конвенціях, багатосторонніх договорах у сфері шлюбу та розлучення.

Саме колізійні норми, що визначають право, яке підлягає застосуванню до розірвання шлюбу, спрямовані на подолання численних суперечностей і неузгодженостей у сімейному праві окремих держав, у тому числі до згаданої вище ситуації, - і сьогодні нерідко шлюб, розірваний в одній державі, продовжує існувати в іншій. Як підкреслюється в юридичній літературі [12, с. 129], це пов'язано, насамперед з тим, що незважаючи на реформування сімейного права і введення в кінці минулого століття інституту розлучення і в католицьких країнах, в окремих державах розлучення не допускається і зараз (наприклад, у деяких країнах Латинської Америки); у ряді держав можливість розлучення обмежена суворо встановленими в законі випадками (у Великій Британії, Італії та ін.) Особливий підхід до розірвання шлюбу властивий мусульманським країнам.

Що ж стосується держав, де допускаються розлучення, загальним колізійним принципом розірвання шлюбу визнається закон громадянства подружжя або чоловіка (більшість країн континентальної Європи) або закон місця проживання подружжя (Англія, США та ін.). Водночас іноземний законодавець вважає, що для регулювання розлучення повинні використовуватися прив'язки, що визначають особисті відносини між подружжям. Крім того, аналіз колізійних норм іноземного законодавства свідчить, що для врегулювання розірвання шлюбу застосовуються також численні різноманітні додаткові прив'язки.

Наприклад, згідно зі ст. 61 Закону Швейцарії "Про міжнародне приватне право" розлучення і встановлення ре- 
жиму окремого проживання подружжя регулюють швейцарським правом (1); у тих випадках, коли подружжя, місце проживання одного з них $є$ у Швейцарії, і вони мають спільне іноземне громадянство, застосовують право їхнього спільного громадянства (2). У тих випадках, коли іноземне право спільного громадянства подружжя забороняє розірвання шлюбу або підкоряє його надмірно суворим умовам (тобто обмежує розірвання шлюбу), застосовують швейцарське право, якщо одне з подружжя має, крім іноземного, ще і швейцарське громадянство або проживає у Швейцарії не менше двох років (3). Швейцарський суд за місцем походження одного з подружжя, $є$ компетентним в силу ст. 60, застосовувати швейцарське право (4). Водночас згідно із Законом Бельгії "Про міжнародне приватне право", право, що підлягає застосуванню щодо розірвання шлюбу, не застосовується, якщо воно не визнає розлучення (§ 3 ст. 55) [12, с. 129].

Порядок колізійного регулювання у Німеччині, здійснюється за школою Кегеля, що встановлена ст. 14 Вступного закону до Німецького цивільного уложення. До вказаного порядку, як звертає увагу у своїй праці В. І. Кисіль, відсилає "ст. 17(1) про розлучення із застереженням на користь того з подружжя, хто має німецьке громадянство, у випадку, якщо закон, що застосовується відповідно до шкали Кегеля, не дозволяє розлучення", передбачаючи також положення про обов'язок одного 3 колишнього подружжя сплачувати іншому компенсацію після розірвання шлюбу, яка "поширювалася також на розподіл майнового права на пенсію, набутого одним із подружжя за час перебування у шлюбі, на користь іншого 3 подружжя, який не набув таких прав, але за рішенням суду має право претендувати на половину майна та майнових прав. Ця компенсація спрямована на захист передусім дружини-домогосподарки, яка не мала змоги працювати й набути права на пенсію" [2, с. 273-274].

У свою чергу законодавство Австрії містить схожі тенденції у сфрері колізійного регулювання шлюбносімейних відносин. Зокрема, як наголошується в юридичній літературі, "одним з фундаментальних положень гл. 3 Закону про міжнародне приватне право 1978 р. стосовно сімейного права $€$ колізійний припис параграфа 18 (1), який регулює колізійні питання правових наслідків шлюбу. Указана норма нагадує проаналізовану вище шкалу Кегеля, але $є$ менш детальною. На систему прив'язок, установлену у параграфрі 18 , указують також положення параграфа 19 закону (про вирішення колізій у майнових відносинах подружжя із застереженням про автономію волі) та параграфа 20 закону (про колізійні питання розлучення)", де передбачено, що підстави і наслідки розлучення визначаються законом, що регулює особисті правові наслідки шлюбу на момент розлучення, із застереженням, що на випадок відсутності всіх пов'язуючих факторів, зазначених у параграфрі 18, розлучення здійснюється за особистим законом позивача на момент розірвання шлюбу" [2, с. 275].

Серед міжнародно-правових актів, що присвячені уніфікації колізійного регулювання розлучення (уніфікація матеріальних сімейно-правових норм унаслідок різноманітності внутрішнього законодавства $€$ вкрай ускладненою), слід виокремити, насамперед, Гаазьку конвенцію про визнання розлучень і рішень щодо окремого проживання подружжя від 1 червня 1970 р.

Зокрема, Гаазька конвенція [13] стосується не колізій законів, а лише питань визнання в договірних державах розлучень і рішень про роздільне проживання подружжя. Конвенція не застосовується щодо встановлення вини, щодо додаткових приписів суду, що зроблені при винесенні рішення про розлучення або роздільне проживання подружжя; зокрема, вона не застосовується до приписів, що стосуються майнових зобов'язань або опіки над дітьми (ст. 1).

Для визнання рішень необхідним $є$ дотримання однієї з установлених у цій Конвенції умов: відповідач або позивач мають у державі, де відбулося розлучення або прийняття рішення про окреме проживання подружжя, звичайне місце проживання; обидва з подружжя - громадяни цієї держави; позивач - громадянин цієї держави і має у ній звичайне місце проживання; позивач проживає цій у державі протягом одного року або частинами впродовж двох років, що передують даті пред'явлення позову; позивач $є$ громадянином цієї держави і перебуває в цій державі на момент пред'явлення позову, та подружжя проживало останнім часом разом у державі, право якої, у період порушення справи, не передбачало розлучення (ст. 2).

Конвенцією передбачено, що у визнанні розлучень i рішень про роздільне проживання подружжя не може бути відмовлено з підстав, що закон держави, в якій ставиться питання про визнання, не допускає розлучення та рішення про роздільне проживання подружжя, або на тій підставі, що був застосований закон інший, ніж той, який був би застосовний за правилами міжнародного приватного права цієї держави (ст. 6). Якщо обидва з подружжя на момент вчинення розлучення були громадянами тільки тієї держави, закон якої не визнає розлучення, тоді будь-яка договірна держава може відмовити у такому визнанні (ст. 7). Конвенція не перешкоджає застосуванню у Договірній державі більш сприятливих для визнання вчинених за кордоном розлучень і рішень про роздільне проживання подружжя норм права.

Таким чином, поряд із розірванням шлюбу, яке припиняє правовідносини між подружжям, сторони можуть використовувати іншу можливість у сфері розлучення. А саме, сторони вправі, якщо це передбачено правовою системою, просити суд про винесення рішення про сепарацію (separation de corps, Separation, separation) - роздільне проживання подружжя. У цьому випадку шлюб не припиняється, але подружжя отримує право окремого проживання. Часто судова сепарація є стадією, що передує розлученню (наприклад, у Великій Британії, Франції, Італії, Швейцарії та США). Якщо під час сепарації одне з подружжя помирає, то інше не втрачає спадкових прав.

Одним із визначальних моментів у регулюванні сімейно-правових відносин у країнах Європейського Союзу на сучасному етапі стало прийняття 2000 року Хартії основних прав [14]. Положення, що стосуються регулювання сімейного життя, розкидані по всьому тексту Хартії. У першу чергу йдеться про ст. 7 Хартії, відповідно до якої кожна людина має право на повагу до її приватного і сімейного життя, на недоторканність житла й таємницю кореспонденції. Стаття 9 Хартії гарантує право на укладення шлюбу і право на створення сім'ї згідно з національним законодавством, що регламентує реалізацію цього права. Стаття 33 Хартії врегульовує питання охорони сім'ї, яка забезпечується на юридичному, економічному й соціальному рівнях. 3 метою забезпечення можливості поєднувати сімейне життя і професійну діяльність кожній жінці надається право на захист від звільнення на підставі її вагітності, а також право на оплачувану відпустку у зв'язку з вагітністю й пологами, післяпологову відпустку або відпустку у зв'язку з усиновленням дитини.

Основним нормативним актом ЄС у сфері регулювання відносин розлучення та колізійних питань, що виникають у разі розлучення є Регламент Ради Європейського Союзу № 1259/2010 від 20 грудня 2010 р. про розширення співпраці в галузі права, що застосовується до розірвання шлюбу і судового розлучення подружжя [15].

Регламент 1259/2010 (відомий як "Регламент Риму III") нині застосовується в 17 державах-членах. Ірландія та Великобританія не прийняли цього Регламенту. Перші два Регламенти - № 593/2008 Європейського Парламенту та Ради від 17 червня 2008 р. "Про право, що підлягає застосуванню до договірних зобов'язань" і № 864/2007 "Про право, що підлягає застосуванню до 
недоговірних зобов'язань" визначили загальну тенденцію гармонізації колізійних норм ЄС в області цивільних і торгових справ. Регламент 1259/2010 продовжив цей напрямок у досить вузькій галузі правовідносин, а саме - шлюбно-сімейних відносин, ускладнених іноземним елементом, причому лише щодо розірвання шлюбу $\mathrm{i}$ судового розлучення подружжя. Цей документ передбачає по суті своїй інноваційні положення, що пояснює, у свою чергу, непросту історію його прийняття. Уперше закріплено можливість самостійно вибирати подружжю застосовне право при розірванні шлюбу або судовому розлученні, що на сьогодні дійсно виступає свого роду революцією в колізійно-правовому регулюванні розірвання шлюбу в міжнародному сімейному праві.

Зазначимо, що цей Регламент не поширюється на питання визначення правоздатності, наявності, дійсності і визнання шлюбу, недійсності шлюбу, права на ім'я подружжя, майнові відносини між подружжям, права і обов'язки батьків, аліментні зобов'язання й успадкування.

У вказаному Регламенті передбачено і ланцюжок колізійних прив'язок, що дозволяють вибрати застосовне право в тому випадку, якщо чоловік і жінка самостійно не здійснили такий вибір. Як застосовне право також виступає право країни громадянства або місця проживання подружжя, або право країни суду.

\section{ВИСНОВКИ}

Проведене дослідження генезису правового регулювання порядку, умов і наслідків розірвання шлюбу, а також сучасних засад регламентації сімейних відносин у праві $€ C$ та за законодавством окремих іноземних держав дозволяє зробити такі висновки.

По-перше, процедура розлучення, її умови та правові наслідки регулюються законодавством різних держав по-різному. На регулювання відносин із розірвання шлюбу також суттєво впливають національні особливості, традиції, релігія та культура. Поширення сімейних правовідносин за межі однієї держави викликає необхідність застосування для регулювання таких відносин іноземного законодавства. Наслідком застосування права різних держав щодо підстав розлучення, процедури розірвання шлюбу, а також неоднакового визначення моменту його припинення, може бути виникнення відповідних колізій, що зумовлює практичне значення визнання наслідків розлучення, здійсненого за правом однієї держави в іноземних правопорядках.

По-друге, одним 3 основних принципів римського приватного права було дотримання абсолютної свободи розлучення. Проте в імператорський період, та особливо з утвердженням християнства, були встановлені обмеження для розлучення.

Підхід щодо суттєвого обмеження та навіть його заборони впродовж тривалого часу спостерігався у праві європейських держав. Під впливом католицької церкви та християнської моралі рецепійоване право взагалі не допускало розлучення чи встановлювало обмеження та вагомі підстави розлучення. Розірвання шлюбу допускалося лише як виняток, за наявності істотних обставин, з додержанням ускладнених процедур.

По-третє, починаючи з другої половини XX ст. у багатьох країнах були проведені реформи законодавства про розлучення, тенденцією яких стала відмова від ідеї, що розлучення - це санкція за винну поведінку подружжя, та перехід до концепції, що розлучення - це констатація невдалого шлюбу. Унаслідок реформ законодавство про розлучення стало більш лібералізованим.

По-четверте, загальним колізійним принципом розірвання шлюбу визнається закон громадянства подружжя (більшість країн континентальної Європи) або закон місця проживання подружжя (Англія та ін.). Однак, Регламент ЄС № 1259/2010 передбачає інноваційні положення щодо обрання компетентного правопорядку у разі розлучення, закріплюючи можливість самостійного обрання подружжям застосовного права.
Список використаних джерел

1. Міжнародне приватне право. Загальна частина: підручник / за ред. А.С. Довгерта і В.І. Кисіля. - К.: Алерта, 2012. - 376 с.

2. Кисіль В.І. Міжнародне приватне право: питання кодифікації. 2-е доповн. і перероб. вид. - К.: Україна, 2005. - с.271-280.

3. Римское частное право: Учебник / Ред.И.Б. Новицкий, И.С. Перетерский. - М.: Юристъ, 2001, 2004

4. Дождев Д.В. Римское частное право: Учебник для студ. вузов, обуч. по спец. "Юриспруденция" /Д.В. Дождев; ред В.С. Нерсесянц; Ин-т гос-ва и права РАН, Академич. правовой ун-т.-2-е изд., изм. и доп. - М.: HOРМА; М.: ИНФРА-М, 1999, 2000, 2003

5. Цивільний кодекс для Східної Галіції 1797 p. Codex civilis pro Galicia Orientali anni MDCCXCVII.: 2-ге вид., доопр. / пер. з лат. А.Гужви; За ред. О. Кутателадзе, В. Зубара. Київ: Юрінком інтер, 2018. - 660 с.

6. Code civil. Version consolidée au 25 mars 2019. URL: https://www.legifrance.gouv.fr/affichCode.do?cidTexte=LEGITEXT000006070721

7. Закон Франції № 2013-404 від 17 травня 2013р. про дозвіл на шлюб для одностатевих пар // LOI n² 2013-404 du 17 mai 2013 ouvrant le mariage aux couples de personnes de même sexe. URL: https://www.legifrance.gouv.fr/affichTexte.do?cidTexte=JORFTEXT0000274 14540\&categorieLien=id

8. Германское гражданское уложение. URL: http://www.twirpx.com/ file/250517/ 33

9. Dutch Civil Code. URL: http://www.dutchcivillaw.com/legislation/ dcctitle $771010 . \mathrm{htm}$

10. Codice Civile della Reppublica Italiana del 16 marzo 1942. URL: https://www.gazzettaufficiale.it/sommario/codici/codiceCivile

11. Legge del 1 dicembre 1970, n. 898 "Disciplina dei casi di scioglimento del matrimonio", articolo 3. URL: https://www.normattiva.it/uri-res/ N2Ls?urn:nir:stato:legge:1970;898

12. Марышева Н.И. Семейные отношения с участием иностаранцев: правовое регулирование в России / Н.И. Марышева. - М.: Волтерс Клувер, 2007. - С.129.

13. Конвенция о признании разводов и решений о раздельном жительстве супругов. від 01.06.1970. OOH. URL: http://zakon4.rada.gov.ua/ laws/show/995 925 .

14. Хартія основних прав Європейського Союзу. URL: https://zakon.rada.gov.ua/laws/show/994_524\#Text

15. Council Regulation (EU) No 1259/2010. URL: https://eur-lex.europa.eu/ legal-content/GA/TXT/?uri=celex\%3A32010R1259.

\section{References}

1. Mizhnarodne pryvatne pravo. Zahalna chastyna pidruchnyk (2012) [Private international law. General part: textbook]. Za red. A.S. Dovherta i V.I. Kysilia. K., Alerta (in Ukrainian).

2. Kysil V.I. (2005) Mizhnarodne pryvatne pravo: pytannia kodyfikatsii. [Private international law: the question of codification.] 2-e dopovn. pererob. vyd. K., Ukraina (in Ukrainian).

3. Rymskoe chastnoe pravo: Uchebnyk (2001) [Roman private law: Textbook] / Red.Y.B. Novytskyi, Y.S. Pereterskyi.-M., Yuryst, 2001, 2004. (in Russian).

4. Dozhdev D.V. (2003) Rymskoe chastnoe pravo [Roman Private Law]. Uchebnyk dlia stud. vuzov, obuch. po spets. "lurysprudentsyia" D.V. Dozhdev; red V.S. Nersesiants; Yn-t hos-va y prava RAN, -2-e yzd., yzm. y dop.-M.: NORMA; M.: YNFRA. (in Russian).

5. Tsyvilnyi kodeks dlia Skhidnoi Halitsii 1797 (2018). Codex civilis pro Galicia Orientali anni MDCCXCVII. [Civil Code for Eastern Galicia in 1797] 2-he vyd., doopr. / per. z lat. A.Huzhvy; Za red. O. Kutateladze, V. Zubara. Kyiv: Yurinkom inter. (in Ukrainian).

6. Code civil. Version consolidée au 25 mars 2019. [Civil code. Consolidated version]. URL: https://www.legifrance.gouv.fr/affichCode.do? cidTexte=LEGITEXT000006070721 (in French)

7. Zakon Frantsii № 2013-404 vid 17 travnia 2013r. pro dozvil na shliub dlia odnostatevykh par // LOI n2013-404 du 17 mai 2013 ouvrant le mariage aux couples de personnes de même sexe. [Law of France № 2013404 of May 17, 2013]. URL: https://www.legifrance.gouv.fr/affichTexte.do? cidTexte=JORFTEXT000027414540\&categorieLien=id (in French)

8. Hermanskoe hrazhdanskoe ulozhenye [German civil law]. URL: http://www.twirpx.com/file/250517/ 33 (in Russian).

9. Dutch Civil Code. URL: http://www.dutchcivillaw.com/legislation/ dcctitle771010.htm (in Dutch).

10. Codice Civile della Reppublica Italiana del 16 marzo 1942. URL: https://www.gazzettaufficiale.it/sommario/codici/codiceCivile (in Italian).

11. Legge del 1 dicembre 1970, n. 898 "Disciplina dei casi di scioglimento del matrimonio", articolo 3: URL: https://www.normattiva.it/uri-res/ N2Ls?urn:nir:stato:legge:1970;898 (in Italian)

12. Marysheva N.Y. (2007) Semeinye otnoshenyia s uchastyem ynostarantsev: pravovoe rehulyrovanye $v$ Rossyy. [Family relations with the participation of foreigners: legal regulation in Russia]. M., Volters Kluver (in Russian)

13. Konventsyia o pryznanyy razvodov y reshenyi o razdelnom zhytelstve supruhov. vid 01.06.1970. OON. [Convention on the Recognition of Divorces and Separation Decisions of Spouses. from 01.06.1970. United Nations] URL: http://zakon4.rada.gov.ua/laws/show/995 925 (in Russian).

14. Khartiia osnovnykh prav Yevropeiskoho Soiuzu [Charter of Fundamental Rights of the European Union]. URL: https://zakon.rada.gov.ua/ laws/show/994_524\#Text (in Ukrainian).

15. Council Regulation (EU) No 1259/2010. URL: https://eur-lex.europa.eu/ legal-content/GA/TXT/?uri=celex\%3A32010R1259 (in English) 
L. Radchenko, Cand. Sc. (Law), Associate Prof.

Taras Shevchenko National University of Kyiv, Kyiv, Ukraine

\section{LEGAL REGULATION OF DIVORCE: HISTORICAL DEVELOPMENT AND MODERN PRINCIPLES}

The article is devoted to the study of the genesis of legal regulation of the order, conditions and consequences of divorce in its historical aspect, as well as given the current principles of family relations in EU law and foreign law, highlighting the latest trends in divorce relations and outlining the laws of their further consolidation in the family law of Ukraine, formulation of conclusions and proposals aimed at harmonization of national legislation with EU law.

The divorce procedure, its conditions and legal consequences are regulated by the legislation of different states in different ways. The regulation of divorce relations is also significantly influenced by national characteristics, traditions, religion and culture. The spread of family relations outside one state necessitates the application of foreign law to regulate such relations. Appropriate conflicts may result from the application of the law of different states regarding the grounds for divorce, the procedure for divorce, as well as the unequal determination of the moment of its dissolution.

The article argues that one of the basic principles of Roman private law was the observance of absolute freedom of divorce. However, during the imperial period, and especially with the establishment of Christianity, restrictions were imposed on divorce.

The approach to significant restrictions and even prohibitions on divorce has long been observed in the law of European states. Under the influence of the Catholic Church and Christian morality, the recipient law did not allow divorce at all or established restrictions and valid grounds for divorce. Divorce was allowed only as an exception, in the presence of significant circumstances, subject to complicated procedures.

Since the second half of the twentieth century, divorce laws have been reformed in many countries, tending to abandon the idea that divorce is a sanction for marital misconduct and moving to the concept that divorce is a statement of a failed marriage. As a result of the reforms, divorces have become more liberalized.

The article concludes that the general conflict principle of divorce is the law of citizenship of a spouse or husband (most countries of continental Europe) or the law of the place of residence of the spouses (England, USA and a number of other countries). However, Regulation 1259/2010 provides, in essence, innovative provisions for the choice of the competent legal order in the event of divorce, which enshrines the possibility for spouses to independently choose the applicable law.

Keywords: marriage, marital relations, divorce, termination of marriage, EU law, family law.

Bulletin of Taras Shevchenko National University of Kyiv.

Legal Studies, 2021; 3 (118): 122-127

УДК 347.98

DOI: https:doi.org/10.17721/1728-2195/2021/3.118-22
ISSN $1728-2195$

(c) Taras Shevchenko National University of Kyiv, Publishing center "Kyiv University", 2021

О. 3. Хотинська-Нор, д-р юрид. наук, зав. каф. Київський національний університет імені Тараса Шевченка, Київ, Україна ORCID ID: 0000-0002-4480-6677

\section{"БЕЗСТОРОННІСТЬ СУДУ" ЯК СТАНДАРТ СПРАВЕДЛИВОГО ПРАВОСУДДЯ: ПРАКТИКА ЄСПЛ I ПЕРСПЕКТИВИ РОЗВИТКУ В УКРАЇНІ}

Досліджено зміст і природу такого усталеного стандарту справедливого правосуддя як безсторонність суду, що широко витлумачений у практиці Єөропейського суду з прав людини. На підставі системного аналізу масиву рішень єСПЛ виокремлено суттєві позиції, що характеризують стандарт безсторонності суду. До них належать такі: 1) безсторонність суду перебуває у дихотомічному зв'язку з категорією "упередженість"; 2) безсторонність суду оцінюється за двома критеріями: (а) суб'єктивним, який перебуває у "площині" особистості судді та його переконань; (б) об'єктивним, який перебуває у "площині" існуючих гарантій і механізмів, якими повинен скористатися суд, щоб уникнути обгрунтованих сумнівів у необ'єктивності та звинувачень в упередженості на свою адресу; 3) визначальний вплив зовнішнього прояву безсторонності суду; 4) раціональна обґрунтованість сумнівів у безсторонності; 5) різноманітність і необмежене коло ситуацій, що можуть породити сумніви у безсторонності суду.

Ураховуючи, що ЄСПЛ оцінює безсторонність національного суду за суб'єктивним і об'єктивним критеріями, їм приділено особливу увагу та визначено специфіку застосування. У процесі аналізу зроблено висновок, що поява таких критеріїв обумовлена складною етико-правовою природою досліджуваного стандарту. Обґрунтовано, що стандарт безсторонності суду сягає своїм корінням моральної основи суддівської професії, що еволющіонувала та трансформувалася у систему правил професійної поведінки та норм законодавства, спрямованих на досягнення мети судочинства та реалізацію особою права на справедливий суд. Етична природа безсторонності суду зумовлює оцінку відповідності цьому стандарту за суб'єктивним показником. Водночас її правова природа, яка охоплює інституціональну та процесуальну складові, спонукає до розвитку в національному законодавстві відповідних гарантій, існування яких є критерієм оцінки безсторонності суду за об'єктивним критерієм. У контексті останньої тези наголошено на особливому значенні інституту відводу (самовідводу) судді як процесуальній гарантії безсторонності суду. Аргументовано, що в національному цивільному, господарському й адміністративному судочинстві правила та порядок відводу судді потребують удосконалення в напрямку реалізації постулату "ніхто не може бути суддею у власній справі".

Ключові слова: безсторонність суду, неупередженість суду, незалежність суду, справедливе правосуддя, право на справедливий суд, критерії оцінки безсторонності суду, стандарти правосуддя.

\section{ВСТУП}

2021 року Україна відзначає 30 років своєї незалежності, 30 років із дня, коли український народ узяв відповідальність за власну долю та розвиток власної нації та держави. Обравши курс на побудову демократичної, правової, соціальної держави, в якій людина є основною цінністю та сповідується принцип верховенства права, Україна стала на складний і тернистий шлях трансформації. Цей шлях характеризується своєю специффікою, зумовленою історичним корінням і традиціями, геополітичним розташуванням і економічною нестабільністю, необхідністю поступової еволюції правової свідомості та культури громадян.

Одним із нагальних питань на шляху розбудови нашої держави, яке всі 30 років її незалежності не втрачає своєї актуальності, є питання організації незалежної судової влади, ефективне функціонування якої $€$ ядром правової держави та необхідним інструментом у механізмі забезпечення верховенства права. Її сучасна модель склалася під впливом різних чинників, визначальним серед яких стала ратифікація Україною 1997 року Конвенції про захист прав людини й основоположних свобод, а разом із нею - визнання юрисдикції Європейського суду з прав людини. Це сприяло якісно новому підходу до розуміння соціально-правової природи та соціального призначення інституту правосуддя, спонукаючи до різного роду кроків на шляху реформування судової влади України задля втілення міжнародних стандартів справедливого правосуддя в державі. Система останніх передбачає складну структуру, множинність вимог, які стосу- 